\title{
A LAND OF MIGRANTS IN THE MEDITERRANEAN. IBERIAN MIGRATORY FLOWS IN SARDINIA BETWEEN THE $12^{\mathrm{TH}}$ AND $15^{\mathrm{TH}}$ CENTURIES
}

\author{
Alessandra Cioppi \\ Istituto di Storia dell'Europa Mediterranea \\ (Consiglio Nazionale delle Ricerche) \\ ITALY
}

Date of receipt: $8^{\text {th }}$ of July, 2016

Final date of acceptance: $13^{\text {th }}$ of September, 2017

\section{Abstract}

The island of Sardinia is a meeting point for three continents, receiving a constant migration since prehistoric times. The migration from the Iberian Peninsula was permanent and consistent between the $12^{\text {th }}$ and $15^{\text {th }}$, as stated in Italian and Spanish sources. In this framework, our approach analyse the internal and external mobility of the population and the intense movement of people, ideas and goods that have profoundly marked the different territorial and urban features of the island. The paper shows the different sizes and types of Iberian migrations in Sardinia and emphasizes the distinction between the first migration (those who migrated to Sardinia taking part in the military conquest of the island by the Infante Alfonso) and the second one (those who participated in the subsequent occupation and domination of the island). ${ }^{1}$

\section{KeYWords}

Sardinia, Mediterranean, Iberian Peninsula, Crown of Aragon, Migration, Trade, Cultural Exchange, $12^{\text {th }}-15^{\text {th }}$ Centuries.

\section{Capitalia Verba}

Sardinia, Mediterraneum, Peninsula Iberica, Corona Aragonum, Migratio, Commercium, Culturae Mutatio, Saecula XII-XV. 


\section{Images and clichés}

When speaking of Sardinia one often refers to a poor, isolated region that has been repeatedly conquered and colonized by invading forces - a land from which people have emigrated rather than to which they have migrated. However, this depiction of the island stems mostly from $19^{\text {th }}$ to early $20^{\text {th }}$ century literature and historiography. The numerous travellers who visited the island and reported their opinions and impressions in travel logs played a significant role in creating this vision of Sardinia.

It is rather disconcerting to find that many selected the island just because it was famed to be a primitive region, rugged and wild, inhabited by singular, bizarre peoples with arcane customs; it thus offered something different from the canons of the European Grand Tour, the educational travels typically undertaken by the rich, young noblemen and women of $18^{\text {th }}$ century England. ${ }^{2}$

The most striking case is that of the English novelist David Herbert Lawrence, whose famous book Sea and Sardinia is based on his visit to Sardinia in 1921. Although he sings high praises of the island, in explaining why he undertook the trip he writes:

Sardinia, which is like nowhere. Sardinia, which has no history, no date, no race, no offering. Let it be Sardinia. They say neither Romans nor Phoenicians, Greeks nor Arabs ever subdued Sardinia. It lies outside; outside the circuit of civilisation $(\ldots) .^{3}$

1. Report presented at the European Migration Network Seminar held in Cagliari on 10 April 2015 and organized by the National Research Council's Institute for the History of Mediterranean Europe (Cagliari), by the Ministry of the Interior (Rome), by the European Migration Network (EMN) and by the National Research Council's Department of Human and Social Sciences (Rome).

2. The practice of grand tours originated in the medieval period, but it is in the $18^{\text {th }}$ century that it became a true rite of passage for the aristocracy. The driving force was English Enlightenment under Elizabeth I, who considered such tours an indispensable instrument for the cultural and spiritual education of the English elite. The proposed essential references include only certain reference texts that either simply describe or offer insights into the phenomenon. See Trease, Geoffrey. The Grand Tour. A History of the Golden age of Travel. New York: Holt, Rinehart and Wintson, 1967; Hibbert, Christopher. The Grand Tour. London: Weidenfeld \& Nicholson, 1969; Pine-Coffi, Robert S. Bibliography of British and American travel in Italy to 1860. Florence: Olschki, 1974; Lord Chesterfield, Philip D. L'educazione del gentiluomo. Lettere al figlio. Milan: Serra e Riva, 1984; Black, Jeremy. The British and the Grand Tour. London: Croom Helm, 1985; De Seta, Cesare; Mozzillo, Atanasio; Vallet, Georges. L'Italia dei grandi viaggiatori. Rome: Abete, 1986; Olschki, Fiammetta. Viaggi in Europa, secoli XVI-XIX. Florence: Olschki, 1990; Peyer, Hans C. Viaggiare nel Medioevo. Dall'ospitalità alla locanda. Rome-Bari: Laterza, 1990; Maczak, Antoni. Viaggi e viaggiatori nell'Europa moderna. Rome-Bari: Laterza, 1992; De Seta, Cesare. L'Italia del Grand Tour. Da Montaigne a Goethe. Naples: Electa, 1992; Brilli, Attilio. Quando viaggiare era un'arte. Il romanzo del Grand Tour. Bologna: Il Mulino, 1995 and by the same author Brilli, Attilio. Arte del viaggiare. Il viaggio materiale dal XVI al XIX secolo. Milan: Silvana Editoriale, 1992.

3. Lawrence, David H. Sea and Sardinia. New York: Thomas Seltzer, 1921: 15, see also page 6 of the online version: <http://www.freeclassicebooks.com/Lawrence \%20D\%20H/Sea\%20and\%20Sardinia. pdf $>$ (Consulted $7^{\text {th }}$ June 2016). 
One could continue with many other similar examples, all of which have a common denominator: they do not explore the island's multiform and stratified history but paradoxically and inexplicably fail to acknowledge its complexity. ${ }^{4}$

Without adding to or detracting from the value of these testimonies - which were in any case in accord with the opinions of historians of the period-,${ }^{5}$ one must consider that they mainly reflected the situation on the island at the time: its difficulties and poverty, its actual economic and social backwardness, its isolation from communication networks. Nevertheless, these judgements cannot be extended to the whole of Sardinian history or be transferred from the $19^{\text {th }}$ century to other periods in time, nor can they be considered the only possible historiographical interpretation.

\section{History of conflicts and integration}

The testimony of $19^{\text {th }}$ and $20^{\text {th }}$ century travellers and interpretations of the historiography of the period reveals two main aspects: firstly, the certainty that is image of Sardinia is a cliché repeated slavishly throughout its history and, secondly, the impression that the history of Sardinians differs and is distinct from that of the numerous invaders.

A history - that of Sardinians - which differs from the official one depicting submission and lack of expectation, with no signs of integration or common development. A history of rebellion and constant struggles against foreign powers, of lost battles and magnificent heroism, which encouraged the theorization of a Sardinian identity that was never conquered, never violated by any foreign invasion, unchanged and unchangeable throughout the centuries, especially in the innermost reaches of the island, that is in the inaccessible and rebellious Barbagia. A perspective which, followed by many, saw its maximum expression in the theory of the "the constant of Sardinian resistance", formulated by the famous Sardinian archaeologist Giovanni Lilliu; in an article addressing this topic he claimed that

\footnotetext{
4. Smyth, William Henry. Sketch of the present state of the island of Sardinia. London: John Murray, 1828; Pasquin, Antoine-Claude [Valery]. Viaggio in Sardegna, ed. Maria Grazia Longhi. Nuoro: Ilisso, 1996 (original edition: Pasquin, Antoine-Claude [dit Valery]. Voyages en Corse, a l'ile d'Elbe, et en Sardaigne. Paris: Bourgeois-Maze, 1836-1837); Marmora, Alberto della. Voyage en Sardigne de 1819 à 1825 ou Description statistique, physique et politique de cette Ile, avec des recherches sur ses productions naturelles et ses antiquités. Paris: Ed. Dela forest de Arthus Bertrand, 1826. Eduardo Chicharro Agüera and Antonio Ortiz Echagüe, two of the leading painters of the Costumbrism movement in Spain between the $19^{\text {th }}$ and $20^{\text {th }}$ centuries, visited Sardinia in 1901 and in the 1906-1909 period, where they had decided to look for subjects to paint that were "outside of any civilization". Their paintings are true ethnographic records revealing the sociocultural setting in Sardinia. See Frongia, Maria Luisa. Due pittori spagnoli in Sardegna. Eduardo Chicharro Agüera (1901) e Antonio Ortiz Echagüe (1906-1909). Catalogo della mostra. Nuoro: Ilisso, 1995.
}

5. Carta Raspi, Raimondo. Breve storia di Sardegna. Cagliari: Ed. Fondazione Il Nuraghe, 1950; Manno, Giuseppe. Storia di Sardegna. Milan: Ed. Placido Maria Visai, 1835 and Manno, Giuseppe. Storia moderna della Sardegna del barone Giuseppe Manno. Dall'anno 1773 al 1799. Turin: Fratelli Favale, 1842; Bellieni, Camillo. La Sardegna e i sardi nella civiltà del mondo antico. Cagliari: Ed. Fondazione Il Nuraghe, 1928-1931. 
la Sardegna in ogni tempo ha avuto uno strano marchio storico: quello di essere sempre dominata (...), ma di avere sempre resistito. Un'isola sulla quale è calata per $i$ secoli la mano oppressiva del colonizzatore, a cui ha opposto, sistematicamente, il graffio della resistenza. Perciò, $i$ Sardi hanno avuto l'aggressione di integrazioni di ogni specie ma, nonostante questo, sono riusciti a conservarsi sempre se stessi. Nella confusione etnica e culturale che li ha inondati per millenni, sono riemersi, costantemente, nella fedeltà alle loro origini autentiche e pure. ${ }^{6}$

Is this really true? Has the history of Sardinia really always been distinctly separate from that of the Phoenicians and Carthaginians, the Romans, Genoese, Pisans and Catalan-Aragonese? And is it a good thing to base historic interpretation on opposed ethnic groups rather than, for example, on the activities and development of social groups? And was Barbagia really so inaccessible and unspoiled?

Depending on the historical period, there are numerous possible, often contradictory, answers. In this sense the topic of migrations can provide essential elements for clarifying and verifying different theories and situations.

Migratory phenomena can no doubt be considered relatively new phenomena. Although they have served to populate the various continents and represent a significant factor in demographic and economic development, they have and always will create forms of mistrust and conflict. Ever since antiquity, nations and rulers have continuously attempted to channel and control both mass and individual migratory flows. ${ }^{7}$

Lying at the centre of the Mediterranean and at the meeting point of three continents, Sardinia has witnessed continuous migratory flows since prehistoric times. As I do not wish to address the problem of mobility in the long term, I will not discuss the Phoenician, Phoenician-Punic or Roman colonizations. Nor will I touch upon Tuscan or Ligurian colonizations, although these would merit lengthy

6. "Every period of Sardinian history has a peculiar hallmark: that of always being dominated (...), but of always having resisted. An island on which the oppressive hand of colonizers ruled for centuries and against which the resistance fought constantly tooth and nail. Although Sardinians experienced all sorts of forced integrations, they were nevertheless able to maintain their identity. In the ethnic and cultural confusion that inundated the island for millennia, they always re-emerged, faithful to their authentic, pristine origins". Lilliu, Giovanni. La costante resistenziale sarda, ed. Antonello Mattone. Nuoro: Ilisso, 2002: 225-237, especially 225.

7. Pini, Antonio Ivan. Le grandi migrazioni umane nell'antichità e nel Medioevo. Florence: La Nuova Italia, 1969; Sordi, Marta, ed. Emigrazione e immigrazione nel mondo antico, Milan: Vita e Pensiero, 1994; Sordi, Marta, ed. Coercizione e mobilità umana nel mondo antico, Milan: Vita e Pensiero, 1995; Cavaciocchi, Simonetta, ed. Le migrazioni in Europa, secoli XIII-XVIII. XXV Settimana di studi dell'Istituto "F. Datini" di Prato, Florence: Le Monnier, 1994; Balard, Michel; Ducellier, Alain, eds. Coloniser au Moyen Âge, Paris, 1995; Pizzorusso, Giovanni; Sanfilippo, Matteo. “Rassegna Storiografica sui fenomeni migratori a lungo raggio dal basso Medioevo al secondo Dopoguerra". Bollettino di Demografia storica, 13 (1990), monographic number; Fontaine, Laurence. “Gli studi sulla mobilità in Europa nell'età moderna: problemi e prospettive di ricerca". Quaderni storici, 93 (1996): 739-756; Petti Balbi, Giovanna, ed. Comunità forestiere e "nationes" nell'Europa dei secoli XIII-XVI, Naples: Gisem-Liguori Editore, 2001; Koser, Khalid. International migration. A Very Short Introduction. Oxford: Oxford University Press, 2007; Pizzorusso, Giovanni. "Mobilità e flussi migratori prima dell'età moderna: una lunga introduzione". Archivio storico dell'emigrazione italiana, 3 (June, 2007): 205-222 <http://www.asei.eu/it/2007/06/> (Consulted $7^{\text {th }}$ June 2016). 
discussion; it should be noted that movement from Pisa and Genoa to the island was not only for economic reasons or conquest and that it had highly significant demographic, social, anthropological, economic and political implications. ${ }^{8}$ In Sardinia, Pisans and Genoese built castles, founded villages and, Pisa especially, built cities that would play an important role in the events of the island, for example Villa di Chiesa (present-day Iglesias) and Castel di Castro (present-day Cagliari).$^{9}$

Not only. Many members of the nobility, thanks to diplomatic agreements and matrimonial ties, became a part of the reigning dynasties in the four states, better known as the giudicati, into which Sardinia was divided at the time. Such complete integration allowed these outsiders not only to acquire power but to also form new families of second-generation Pisans in Sardinia; their acquired sovereignty and new prerogatives sometimes brought them into conflict with their places of origin and affiliation. This occurred, for example, between certain Pisan houses (e.g. the Visconti family and the marquises of Massa) and the Commune of Pisa, and between the Doria and the Commune of Genoa. ${ }^{10}$

\begin{abstract}
8. Artizzu, Francesco. Documenti inediti relativi ai rapporti economici tra la Sardegna e Pisa nel Medioevo. Padova: Cedam, 1961; Artizzu, Francesco. Pisani e Catalani nella Sardegna medioevale. Padova: Cedam, 1974 and Artizzu, Francesco. La Sardegna pisana e genovese. Sassari: Chiarella, 1985. See also Meloni, Giuseppe. "La Sardegna nel quadro della politica mediterranea di Pisa, Genova, Aragona". Il Medioevo dai giudicati agli Aragonesi. Storia dei Sardi e della Sardegna, Massimo Guidetti, ed. Milan: Jaca Book, 1987: II, 49-96; Tangheroni, Marco. "Pisa e Sardegna: profondità di un rapporto e lacerazioni di un distacco", La Sardegna nel mondo mediterraneo. La storia del mare e della terra, Manlio Brigaglia, ed. Sassari: Gallizzi, 1984: II, 37-43 and by the same author Tangheroni, Marco. "L'eredità pisana e genovese", La Sardegna, Manlio Brigaglia, ed. Cagliari: Edizioni della Torre, 1988: 33-35; Tangheroni, Marco. "L'importanza della Sardegna nella storia di Pisa". Orme pisane in Sardegna, Giovanni Padroni, ed. Pisa: Pacini, 1994 and the collected works in Tangheroni, Marco. Sardegna Mediterranea, Rome: Il Centro di Ricerca, 1983 (Corpus Membranarum Italicarum. Prima Serie, Studi e Ricerche, XXIII) and in Tangheroni, Marco. Medioevo tirrenico. Sardegna, Toscana e Pisa. Pisa: Pacini, 1992.
\end{abstract}

9. Petrucci, Sandro. "Forestieri a Castello di Castro in periodo pisano", Commercio, finanza, funzione pubblica. Stranieri in Sicilia e in Sardegna nei secoli XIII-XV, Marco Tangheroni, ed. Naples: Gisem-Liguori Editore, 1989: 219-276, and the work Petrucci, Sandro. "Tra Santa Igia e Castel di Castro di Cagliari: politica, società, insediamenti pisani nella metà del XIII secolo", S. Igia capitale giudicale. Contributo all'Incontro di Studio "Storia, ambiente fisico e insediamenti umani nel territorio di Santa Gilla (Cagliari)», 3-5 novembre 1983. Pisa: ETS, 1986: 235-241. See also the miscellaneous volume Artizzu, Francesco, ed. Studi su Iglesias medioevale. Pisa: ETS, 1985; Tangheroni, Marco. "I luoghi nuovi della Sardegna medievale", I borghi nuovi. Secoli XII-XIV, Rinaldo Comba, Aldo Angelo Settia, eds. Cuneo: Società per gli studi storici della Provincia di Cuneo, 1993: 137-152, and by the same author, Tangheroni, Marco. La città dell'argento. Iglesias dalle origini alla fine del Medioevo. Naples: Liguori, 1985.

10. The concept has been clearly outlined by Sandro Petrucci in Petrucci, Sandro. Re in Sardegna, a Pisa cittadini. Ricerche sui "domini Sardiniee» pisani. Bologna: Cappelli, 1988 and in Petrucci, Sandro. "Storia politica istituzionale della Sardegna medioevale (secoli XI-XIV)", Il Medioevo dai giudicati agli Aragonesi. Storia dei Sardi e della Sardegna, Massimo Guidetti, ed. Milan: Jaca Book, 1987: II, 97-156. See also Meloni, Giuseppe. Genova e Aragona all'epoca di Pietro il Cerimonioso, I (1336-1354), II (1355-1360), III (1361-1387). Padova: Cedam, 1971-1981. 


\section{The Iberian migratory phenomenon in the $12^{\text {th }}$ and $13^{\text {th }}$ centuries}

I feel it is important, instead, to stop and consider Iberian mobility and migratory flows affecting Sardinia in a constant and substantial way starting from the $12^{\text {th }}$ $13^{\text {th }}$ century. This does not mean that we must senselessly and tiringly go back to the medieval period; we should instead attempt to reconstruct the internal and external mobility of populations that have profoundly characterized the island's varied local and urban contexts. Thanks to these phenomena we can break from the traditional division of the medieval, modern and contemporary periods, which are instead linked seamlessly in a broad period extending from the $13^{\text {th }}-14^{\text {th }}$ century to the $15^{\text {th }}-17^{\text {th }}$ century. ${ }^{11}$

Note that the Catalan-Aragonese had already reached Sardinia in the $12^{\text {th }}$ century and not for the first time in the $14^{\text {th }}$ century, when through armed conquest, in 1323 the Crown of Aragon legitimized the proclaimed Kingdom of Sardinia and Corsica that Pope Bonifacio VIII had offered as a fief to James II of Aragon. ${ }^{12}$

In actual fact, the marriage of Barisone I, giudice of Arborea, to Agalbursa de Bas-Cervera was celebrated in 1157; the latter was the niece of Ramon Berenguer IV, Count-prince of Barcelona, and daughter of his sister Almodis. ${ }^{13}$ The reasons for this marriage can be traced to relationships at the time among Catalonia, Sardinia and Genoa, to the importance of the Mediterranean area to the Catalonians and Genoese, and to the interests of Barisone I of Arborea in extending his dominion over the entire island and to, this end, in creating allies.

11. Moatti, Claudia, ed. La mobilité des personnes en Méditerranée de l'Antiquité à l'époque moderne. Procédures de contrôle de documents d'identificacion. Rome: École française de Rome, 2004; Gabriella, Maria; Bertinelli, Angeli; Donati, Angela, eds. Le vie della storia. Migrazioni di popoli, viaggi di individui, circolazione di idee nel Mediterraneo antico. Rome: Giorgio Bretschneider editore, 2006.

12. Salavert Roca, Vicente. Cerdeña y la expansión mediterránea de la Corona de Aragón 1297-1314. Madrid: Consejo Superior de Investigaciones Científicas, 1956; Del Treppo, Mario. "L'espansione catalanoaragonese nel Mediterraneo". Nuove questioni di Storia Medioevale, Raffaello Morghen, ed. Milan: Marzorati, 1964: XI, 250-300; Santamaría, Alvaro. "Precisiones sobre la expansión marítima de la Corona de Aragón". Anales de la Universidad de Alicante. Historia medieval, 8 (1990-1991): 187-255; Tangheroni, Marco. "Il 'Regnum Sardiniae et Corsicae' nell'espansione mediterranea della Corona d'Aragona. Aspetti economici", XIV Congresso di Storia della Corona d'Aragona (Sassari-Alghero, 1990). Sassari: Carlo Delfino Editore, 1993: I, 49-88; Cadeddu, Maria Eugenia. “Giacomo II e la conquista del regno di Sardegna e Corsica", Medioevo. Saggi e Rassegne, 20 [Special edition: Maria Eugenia Cadeddu, ed. Corona d'Aragona e Mediterraneo: strategie d'espansione, migrazioni e commerci nell'età di Giacomo II] (1995): 251-316 and by the same author Cadeddu, Maria Eugenia. “Frontiere dell'espansione catalano-aragonese nel Mediterraneo. L'epoca di Giacomo II d'Aragona (1291-1327)", Frontiere del Mediterraneo, Maria Eugenia Cadeddu, Maria Grazia Mele, eds. Pisa: ETS, 2003: 31-39.

13. For the origin of Cervera see Duran Sanpere, Antonio; Sobrequés Vidal, Santiago; Fluvià, Armand de. "Cervera", Gran Enciclopèdia Catalana. Barcelona: Enciclopèdia catalana, 1973: V, 38-40 and the related table. For the viscounty of Bas and the vicissitudes of its descendants see Caula Vegas, Francisco. “Orígenes de la casa vizcondal de Bas". Pyrene, 10 (1949): 296-300 and Caula Vegas, Francisco. El vizcondado de Bas y la Casa de Ampurias. Olot: Patronato de Estudios Històricos Olotenses, 1951; Sobrequés, Santiago. "Bas, vescomtat de", Gran Enciclopèdia Catalana, Barcelona: Enciclopèdia catalana, 1971: III, 283-284. For the origins of the Bas-Cervera and Bas-Serra, giudici of Arborea, see the genealogical tables by Costa Paretas, María Mercedes. Genealogie medioevali di Sardegna, Cagliari-Sassari: DueD Editrice Mediterranea, 1984: 373-397 and tables XXXI-XXXIII, 134-139. 
In this context, it is worth noting that many of Agalbursa's Catalonian relations also established themselves in Arborea (as reported in historical records) and contracted marriages with local "donnikelle", thereby acquiring a prominent position in the giudicati hierarchy; ${ }^{14}$ they were accompanied by other nobles of varying provenance and by knights faithful to Catalonia. Even the latter settled on the island and were awarded public offices and property, thanks to which they integrated perfectly in the administrative, economic and social structure of the giudicato. ${ }^{15}$

Ties between Sardinia and the Iberian peninsula, or rather between Sardinia and Catalonia, were no doubt strengthened progressively after the $12^{\text {th }}$ century and commercial contacts increased starting in the $13^{\text {th }}$ century, as confirmed by the presence of Barcelonese merchants in Oristano and Castel di Castro prior to $1300 .{ }^{16}$

In Oristano, for example, the commercial centre of a prosperous agricultural hinterland, there is evidence of intense mercantile activity specialized in Mediterranean commerce —as Carmen Batlle noted - and of warehouses that stored items of different type and origin belonging to numerous Catalan operators: from French fabrics to paper, from painted earthenware bowls to jugs of vinegar, from Saracen leather seats to many other varied types of goods. Even the Catalan colony must have been very important and flourishing - given the presence of a Consul already in 1301-, frequented by the owners and masters of ships used by Pisans to transport goods from Sardinia to the Commune of Pisa. Various historical documents suggest that a large number of merchants were linked to the Cagliari trading centre and that a good number had actually settled there permanently, at least for part of the year. ${ }^{17}$ These businessmen, especially those from Barcelona and Majorca, had made local production and trade agreements with Pisa and had

14. Especially Agalbursa's brother, Ugo-Poncio de Bas-Cervera, a key player in matrimonial negotiations with Barisone I (having married in 1177 Sinispella, daughter of Barisone's brother-in-law and his first wife Pellegrina de Lacon), acquired a prominent position within the giudicati dynastic hierarchy. His son Hugh I inherited the Viscount of Bas in Catalonia and became the giudice of Arborea in 1192. He was succeeded by his firstborn, who acceded the throne of Arborea as Peter II; his descendants all retained the title of viscounts of Bas and giudice of Arborea. These are the giudici who in the second half of the $14^{\text {th }}$ century became the main adversaries of the King of Aragon in Sardinia. See Genealogie medioevali...: 378-379 and 381-382.

15. For details of the first relationships between the Catalan Viscounts and the House of the giudicato of Arborea see Sobrequés Vidal, Santiago. Els barons de Catalunya. Barcelona: Editorial Base, 1961: 3334; Salavert Roca, Vicente. Cerdeña y la expansión mediterranea...: II, 1-3 and Artizzu, Francesco. Pisani e Catalani...: 9-23.

16. Artizzu, Francesco. "Penetrazione catalana in Sardegna nel secolo XII", VI Congreso de Historia de la Corona de Aragón (Cagliari, 1957). Madrid: Ministerio de Asuntos Exteriores, 1959: 87-102; Batlle, Carmen. "Noticia sobre los negocios de mercaderes de Barcelona en Cerdeña hacia 1300", La Sardegna nel mondo mediterraneo. Gli aspetti storici, Manlio Brigaglia, ed. Sassari: Gallizzi, 1981: II, 277-289; Manconi, Francesco. "Alcune considerazioni sull'economia e la società arborense (secc. XIII-XV)", Società e cultura nel giudicato d'Arborea e nella Carta de Logu. Convegno Internazionale di Studi (Oristano, 1992), Giampaolo Mele, ed. Nuoro: ISTAR, 1995: II, 208-212.

17. Batlle, Carmen. "Noticia sobre los negocios"...: 278, 286. The consul of the colony of Cagliari, Ramon de Tolosa, was a citizen of Barcelona. 
formed companies with the most important Pisan families such as the Alliatas, who had immigrated and established themselves permanently in Sardinia. ${ }^{18}$

In practice, in the $13^{\text {th }}$ century the island became an important stop for CatalanAragonese mercantile ships, especially for those heading to Sicily, North Africa and the eastern Mediterranean. The Crown of Aragon's plans to conquer Sardinia was obviously welcomed by Iberian merchants and traders, who saw it as an opportunity to boost their activity and strengthen their presence on the island. ${ }^{19}$

This does not mean that they promoted the campaign, nor that their expectations were fulfilled by it. After its occupation the island no longer had a single class of merchants. There were enormous differences among them, depending on the period, in terms of origin, interests, type of shops, role and local integration. It is obviously impossible to compare a Catalan merchant residing in Cagliari at the end of the $13^{\text {th }}$ century, who formed companies with Pisans, and one residing in the same city at the end of the $14^{\text {th }}$ century. The latter was involved in the conflict between Catalans and Sardinians, lived in a beleaguered city at war and sometimes carried out a corsair-like commerce. The $15^{\text {th }}$ century merchant instead belonged to a family that had established itself on the island a century earlier, was born in Sardinia, and took part in the integration of the Kingdom of Sardinia in the Crown of Aragon and, at the end of the century, in that of Spain. ${ }^{20}$

18. Tangheroni, Marco. Gli Alliata, una famiglia pisana del Medioevo. Padua: Cedam, 1969 and Tangheroni, Marco. "Famiglie nobili e ceto dirigente a Pisa nel XIII secolo". Medioevo Tirrenico.... 197-220.

19. Batlle, Carmen. "Noticia sobre los negocios"...: 279; Del Treppo, Mario. I mercanti catalani e l'espansione della Corona d'Aragona nel secolo XV. Naples: L'arte tipografica, 1972; Tangheroni, Marco; Di Nero, Lilia. Commercio e navigazione nel Mediterraneo medioevale. Rome: Scolastica, 1981; Tangheroni, Marco. Commercio e navigazione nel Medioevo. Rome-Bari: Laterza, 1996 and Tangheroni, Marco. "Il Regnum Sardiniae et Corsicae" ...: 49-88.

20. Di Tucci, Roberto. "Le condizioni dei mercanti stranieri in Sardegna durante la dominazione aragonese". Archivio Storico Sardo, VII (1911): 3-38; Manca, Ciro. Il libro di conti di Miquel Ça-Rovira. Padua: Cedam, 1969; Cabestany Fort, Joan. "I mercanti catalani e la Sardegna", I Catalani in Sardegna, Jordi Carbonell, Francesco Manconi, eds. Cinisello Balsamo: Silvana Editoriale, 1984: 25-34; Manconi, Francesco. “Traffici commerciali e integrazione culturale nel Mediterraneo occidentale fra Quattrocento e Cinquecento". Studi Storici, 4 (1995): 1051-1073. Already in the '70's Marco Tangheroni, in a paper on feudalism in Sardinia in the Aragonesen period (Tangheroni, Marco. "Il feudalesimo in Sardegna in età aragonese". Annali della Scuola Normale Superiore di Pisa, 3/3 [1973]: 861-892, especially 875), called for the study of the most important merchants who funded the conquest of Sardinia and of tax collectors in the Regnum Sardiniae. In recent years, a number of studies have focused on Sardinian-Catalan mercantile trade in the late medieval period; these have described single individuals whose activities provide interesting insights into the period. For example, Soldani, Maria Elisa. “Dalla bottega al feudo: l'ascesa sociale dei de Doni tra Barcellona e la Sardegna nel Basso medioevo", XVIII Congrés Internacional d'Història de la Corona d'Aragó (Valencia, 2004). Valencia: Universitat de Valencia-Fundació Jaume II el Just, 2005: II, 1159-1173 and by the same author Soldani, Maria Elisa. Uomini d'affari e mercanti toscani nella Barcellona del Quattrocento. Barcelona: Consejo Superior de Investigaciones Científicas, 2010; Oliva, Anna Maria. "Andrea Sunyer cittadino di Cagliari e corsaro nella guerra luso-castigliana (1475-1476)", Estudos em homenagem ao professor Doutor José Marques. Porto: Universidade do Porto. Faculdade de Letras, 2006: I, 245-257 and Oliva, Ana Maria. "March Jover uomo del re e uomo dei consiglieri di Cagliari nella Sardegna tra Tre e Quattrocento", Sardegna e Mediterraneo tra Medioevo ed Età Moderna, Maria Giuseppina Meloni, Olivetta Schena, eds. Genoa: Brigati, 2009: 283-327. 


\section{Migratory flows in the $14^{\text {th }}$ century: modes and players}

After the armed conquest of the island, and in any case starting in the $14^{\text {th }}$ century, a real, intense migration began from the Iberian Peninsula to Sardinia, and from the latter to the territories under the Crown of Aragon. It is of great historical and anthropological importance to quantify this migratory flow and identify the persons and categories involved; this can help understand the conquest of Sardinia, reconstruct all its phases and, most importantly, assess the contribution of subjects of the Iberian Confederation to the Crown of Aragon's project of expansion into the Mediterranean, their expectations, and the benefits accorded to each. ${ }^{21}$

All the same, before discussing $14^{\text {th }}$ century Iberian migration to Sardinia, it is important to make a subtle distinction between the first migratory flow, consisting of those who migrated to Sardinia in the footsteps of the Infant Alfonso and those who settled there later in order to take active part in the occupation and domination of the island. ${ }^{22}$

As for the former migration, there is obviously no single complete list of the very many who took part in the conquest; however, there are numerous historical documents, some of which are highly significant and exhaustive. For example, the privileges James II granted to those who volunteered to fight in the Sardinian army reveal the characteristics of future migrants, be they knights or soldiers. The

\footnotetext{
21. Salavert Roca, Vicente. “El problema estratégico del Mediterráneo occidental y la politica aragonesa (siglos XIV y XV)", IV Congreso de Historia de la Corona de Aragón (Palma de Mallorca, 1955). Palma de Mallorca: Diputación Provincial de Baleares, 1959: I, 201-221 and Salavert Roca, Vicente. "Los motivos económicos en la conquista de Cerdeña", VI Congreso de Historia de la Corona de Aragón (Cagliari, 1957). Madrid: Ministerio de Asuntos Exteriores, 1959: 433-445; Tangheroni, Marco. "Il Regnum Sardiniae et Corsicae"...: 49-88; Fábrega Grau, Ángel. “Ayuda económica de la Iglesia a Jaime II de Aragón por la conquista de Cerdeña". Anthologica Annua, 11 (1963): 13-46; Mitjá Sagué, Marina. "Barcelona y el problema sardo en el siglo XIV", VI Congreso de Historia de la Corona de Aragón (Cagliari, 1957). Madrid: Ministerio de Asuntos Exteriores, 1959: 447-459; Orcástegui Gros, Carmen. “Contribución económica de los aragoneses a las empresas de Cerdeña (siglo XIV)", XIV Congresso di storia della Corona d'Aragona, Sassari-Alghero, 19-24 maggio 1990, Sassari: Carlo Delfino, 1993: III, 659-666; Sánchez Martínez, Manuel. "Contributi finanziari di città e ville della Catalogna alla conquista del regno di Sardegna e Corsica (1321 1326)", Medioevo. Saggi e Rassegne, 20 [Special edition: Maria Eugenia Cadeddu, ed. Corona d'Aragona e Mediterraneo: strategie d'espansione, migrazioni e commerci nell'età di Giacomo II] (1995): 317-352; by the same author Sánchez Martínez, Manuel. Pagar al rey en la Corona de Aragón durante el siglo XIV. Barcelona: Consejo Superior de Investigaciones Científicas, 2003; Muñoz Pomer, Maria Rosa. “Las Cortes valencianas y su partecipación en las empresas italianas", XIV Congresso di storia della Corona d'Aragona, Sassari-Alghero, 19-24 maggio 1990, Sassari: Carlo Delfino, 1993: III, 615-628.
}

22. Bagué, Enric. Alfons el Benigne. Barcelona: Editorial Vicens Vives, 1980; Martínez Ferrando, Jesús Ernest. Jaume II. Barcelona: Editorial Vicens Vives, 1980. For further information on this sovereign and his relations with Sardinia see the miscellaneous volume Corona d'Aragona e Mediterraneo: strategie d'espansione, migrazioni e commerci nell'età di Giacomo II, edited by Maria Eugenia Cadeddu (special edition of Medioevo. Saggi e Rassegne), in particular the work of Muñoz Pomer, Maria Rosa; Pinilla Pérez de Tudela, Regina. "Studi e Ricerche dedicati a Giacomo II d'Aragona in Spagna (1850-1995)". Medioevo. Saggi e Rassegne, 20 [Special edition: Maria Eugenia Cadeddu, ed. Corona d'Aragona e Mediterraneo: strategie d'espansione, migrazioni e commerci nell'età di Giacomo II] (1995): 339-460, for the vast number of works it examines. See also Miret Sans, Joaquim. “Itinerario del rey Alfonso III de Catalunya, IV en Aragón, el conquistador de Cerdeña". Boletin de la Real Academia de Buenas Letras de Barcelona, 5 (1909-1910): 56-57. 
documents contain full details of their identity and social condition, their origin, parentage, profession and the reasons that pushed them to take part in the military undertaking. ${ }^{23}$

Nobles, knights and soldiers, however, did not arrive on the island with just the first migratory flow during the conquest. They also represent a large part of the second migration to Sardinia when James II, and Prince Alfonso especially, realized the strategic and military potential of the island's rapid colonization.

A concrete example of the latter migration is that from Castello di Cagliari and from its conquest. In June 1324, when peace was signed between the Crown of Aragon and Pisa, Castel di Castro, an important centre of trade in the Mediterranean and the capital of Pisan dominions on the island, remained in the hands of the Maritime Republic of Pisa. ${ }^{24}$ The Prince, understanding full well the difficulties in conquering the Sardinian-Pisan walled city, both for its position and its imposing fortification, believed he could make it surrender without armed intervention by creating such antagonism as would lead the city to exhaustion and capitulation. He therefore set up an encampment before the fortress and set about transforming the provisory installation into a true city inhabited by settlers from the Iberian homeland, and to which he wished to assign a vast hinterland and a port that could compete with that of Castel di Castro. This new city, which he named Bonaria, was assigned the task of competing economically and demographically with the Sardinian-

23. Zurita, Jerónimo. Anales de la Corona de Aragón. Saragossa: Consejo Superior de Investigaciones Científicas, 1978-1998: III, 159-160; 175; 185-186; Muntaner, Ramon. "Crònica", Les quatre grans cròniques", ed. Ferran Soldevila. Barcelona: Editorial Selecta, 1971: 910 (chapter CCXXI); 914-915 (chapter CXXIII); Cerimoniós, Pere el. "Crònica". Les quatre grans cròniques...: 1009-1023 (chapter 1); Arribas Palau, Antonio. La conquista de Cerdeña por Jaime II de Aragón. Barcelona: Instituto Español de Estudios Mediterráneos, 1952: 141-149; 168-187; 377-383; Cadeddu, Maria Eugenia. “I privilegi reali, nel regno di Sardegna e Corsica all'epoca di Giacomo II e Alfonso IV d'Aragona. Strategie politiche e militari", Los cimientos del Estado en la Edad Media. Chancillerías, notariado y privilegios reales en la construcción del Estado en la Edad Media, Juan Antonio Barrio Barrio, ed. Alcoi: Marfil, 2004: 157-168; Carbonell Boria, María José; Cuñat Ciscar, Virginia María. "Pergamene di Giacomo II d'Aragona nell'Archivio Municipal de Valencia", Medioevo. Saggi e Rassegne, 20 [Special edition: Maria Eugenia Cadeddu, ed. Corona d'Aragona e Mediterraneo: strategie d'espansione, migrazioni e commerci nell'età di Giacomo II] (1995): 99-111; Cuñat Ciscar, Virginia María. "Del privilegio al registro: la relación entre el consell de València y Cerdeña en tiempos de Jaime II y Alfonso IV a través del Archivo Municipal de Valencia”, XIV Congresso di storia della Corona d'Aragona, Sassari-Alghero, 19-24 maggio 1990, Sassari: Carlo Delfino, 1993: III, 329-337; Cadeddu, Maria Eugenia; Muñoz Pomer, María Rosa; Pons Alós, Vicente; Rodrigo Lizondo, Mateu. "Valencianos en la conquista de Cerdeña a través de un registro de 'lletres' del Justicia Civil de Valencia", XVIII Congrés Internacional d'Història de la Corona d'Aragó (València 2004), Rafael Narbona Vizcaíno, ed. Valencia: Universitat de València Fundació Jaume II el Just, 2005: I, 225-250.

24. For details of Pisa's surrender and the peace treaties signed in June 1324 see Artizzu, Francesco. La Sardegna pisana...: 242-251. For a description of Castel di Castro see Finke, Heinrich. Acta Aragonensia. Berlin und Leipzig: Walther Rothschild, 1908: I, 572-573 (doc. No. 373); Scano, Dionigi. Forma Karalis. Cagliari: Società Editoriale Italiana, 1934 and for the forma urbis (plan of the city) and the Pisan model of urban development see the miscellaneous volume Kirova, Tatiana K., ed. Cagliari. Quartieri storici. Castello. Cagliari: Comune di Cagliari, 1985; Tolaini, Emilio. Forma Pisarum. Pisa: Nistri-Lischi, 1979; Franchetti Pardo, Vittorio. Storia dell'urbanistica. Dal Trecento al Quattrocento. Roma-Bari: Laterza, 1994; Garzella, Gabriella. Com'era Pisa: topografia e insediamento. Dall'impianto tardoantico alla città murata del secolo XII. Naples: Liguori, 1990. 
Pisan capital in order to determine a crisis and its spontaneous abandonment. ${ }^{25}$ Although failing in its intent because the Pisans engaged in a last direct battle with the Catalan-Aragons, ${ }^{26}$ the project was nevertheless highly successful in developing and populating Bonaria. The privileges accorded to settlers and economic prospects were so favourable that within a few months a large number of immigrants from every state under the Crown of Aragon reached the island, and the city of Bonaria soon counted more than six thousand inhabitants. ${ }^{27}$

When Castel di Castro opened its gates to Prince Alfonso, ${ }^{28}$ not peaceably as Alfonso had predicted but after another fierce battle, the city was immediately repopulated with Catalans and all citizens of Pisa were systematically expelled. In short, whereas the Prince's plan to conquer Cagliari had been conceived and planned well, his policy for repopulating the castle (a key element of the newly established reign abroad) varied, was difficult to implement and seemed sometimes contradictory. In the end Bonaria was abandoned definitively and Castell de Càller was established with some difficulty; as the capital of the new Catalan-Aragon Regnum Sardiniae et Corsicae, it became a totally Iberian city, maintaining this physiognomy in subsequent decades. ${ }^{29}$

It is here important to note the use of migration as an instrument of conquest and dominion. Throughout its dominion over the island, the Crown of Aragon widely

25. At the general headquarters on "Buen Ayre" hill Zurita reports that Prince Alfonso mandó labrar una villa con su castillo que le puso nombre Bonayre ["gave instructions for a villa and its castle which he named Bonayre"], suggesting that the hill was named so by the Catalan-Aragonese. For the Bonaria placename see Zurita, Jerónimo. Anales...: 3, vi, LIv, 207; Scano, Dionigi. Forma Karalis...: 26; Costa Paretas, María Marcedes. El Santuari de Santa Maria de Bonaire a la ciutat de Caller. Cagliari: Ettore Gasparini, 1973; Porrà, Roberto. "La questione dell'origine del toponimo Buenos Aires". Medioevo. Saggi e Rassegne, 13 (1988): $171-187$.

26. For the sorties and attacks around the Pisan and the Catalan-Aragonese strongholds see Zurita, Jerónimo. Anales...: 3, vI, LX, 224-227 and Casula, Francesco Cesare. La Sardegna aragonese...: I, 171 -177. 27. For the settlement of Bonaria see Zurita, Jerónimo. Anales...: 3, vI, LV, 209; Todde, Giovanni. “Castel de Bonayre: il primo insediamento catalano-aragonese in Sardegna", XI Congresso di Storia della Corona d'Aragona (Palermo-Trapani-Erice, 1982). Palermo: Accademia di Scienze, Lettere e Arti, 1984: IV, $335-346$ and Contu, Maria Giovanna. "Bonaria roccaforte catalano-aragonese: quale natura giuridica?". Quaderni Bolotanesi, 12 (1986): 139-148.

28. For the capitulation of Castel di Castro and the final surrender of Pisa in June 1326 see especially Arribas Palau, Antonio. La conquista...: 429-430; Casula, Francesco Cesare. La Sardegna aragonese...: I, 206-211 and by the same author Casula, Francesco Cesare. "I trattati diplomatici sardo-aragonesi del 1323-1326", Sardegna, Mediterraneo e Atlantico tra Medioevo ed Età Moderna: Studi storici in memoria di Alberto Boscolo. I. La Sardegna, Luisa D’Arienzo, ed. Rome: Bulzoni Editore, 1993: 207-220. The triumphant entry of the Catalan-Aragonese into Castello di Cagliari is described well in "Cronica del magnificentissimo signore Ramon Muntaner", Cronache catalane del secolo XIII e XIV, eds. Leonardo Sciascia; Filippo Moisé. Palermo: Sellerio, 1984: 381-383 (chapter 290).

29. The Pisan evacuation from Castello di Cagliari and the city's repopulation with Catalans alone is duly described in great detail by Conde Delgado de Molina, Rafael. Castell de Càller. Cagliari catalanoaragonese. Cagliari: Istituto sui rapporti italo-iberici-Consiglio Nazionale delle Ricerche, 1984 and Urban, Maria Bonaria. "Nuovi elementi di storia urbana nel regno di Sardegna. Dalla fondazione di Bonaria al popolamento catalano di Castel di Cagliari". Anuario de Estudios Medievales, 27/2 (1998): 819-866 and by the same author Urban, Maria Bonaria. “Da Bonaria a Cagliari: problemi politici e scelte urbanistiche nel primo periodo del regno di Sardegna catalano-aragonese". Medioevo. Saggi e Rassegne, 22 (1998): $93-148$. 
adopted the expedient of repopulating key centres of the island through migration flows from Iberia. Other examples are Sassari in $1329^{30}$ and Alghero in the mid $14^{\text {th }}$ century. The latter especially, after a long siege and its definitive conquest by King Peter IV of Aragon in 1354, was largely repopulated. Catalans from the western coast of Sardinia flowed into the city to guarantee its defence, and therefore control of one of the island's most strategic areas. ${ }^{31}$

The methods used to promote migratory flows were those used from the start at Castell de Càller: economic and juridical advantages, various exemptions, safe conducts, debt moratoria, food aid, funding of the voyage from the Iberian peninsula to Sardinia and, most important of all, the concession of land, homes and feudal estates. $^{32}$

30. Solmi, Arrigo. "Una pagina di storia sassarese". Archivio Storico Sardo, 4/3 (1908): 373-384; Pala, Giuseppe. "Una nota sul ripopolamento di Sassari al tempo di Alfonso il Benigno". Annali della Facoltà di Lettere e Filosofia, 1/38, 1976-1977 (1980): 133-161; Miret Sans, Joaquim. "Saqueig de Sasser en 1329". Boletin de la Real Academia de Buenas Letras de Barcelona, 4 (July a September 1908): 429-447; Costa Paretas, María Mercedes. "Oficials de la Corona d'Aragó a Sardenya (segle XIV). Notes biogràfiques". Archivio Storico Sardo, 39 (1964): 323-377 and Costa Paretas, María Mercedes. "Oficials de Pere el Cerimonios a Sasser (1336-1387)", La Sardegna nel mondo mediterraneo. 2. Gli aspetti storici, Manlio Brigaglia, ed. Sassari: Gallizzi, 1981: 291-314.

31. Bertran Roigé, Prim. "Les respostes de la baixa noblesa catalana al reclam de Pere el Ceremoniós per anar a Sardenya (1354)", La corona catalanoaragonesa i el seu entorn mediterrani a la baixa edat mitjana, María Teresa Ferrer Mallol, Josefina Mutgé Vives, Manuel Sánchez Martínez, eds. Barcelona: Consejo Superior de Investigaciones Científicas, 2005: 1-22; Turull Rubinat, Max. "Respostes de nobles i cavallers de la vegueria de Cervera per a la campanya de Sardenya de 1354-1355". Miscel-lània Cerverina, 12 (1998): 131-134; Català Roca, Pere. "Pena d'exili a Sardegna", Sardegna, Mediterraneo e Atlantico tra Medioevo ed Età Moderna: Studi storici in memoria di Alberto Boscolo. I. La Sardegna, Luisa D'Arienzo, ed. Rome: Bulzoni Editore, 1993: 337-340; Català Roca, Pere; Gala Fernández, Joan. “Entorn de 'Lo bon ayre e la noblea d'esta illa de Sardenya'", XIV Congresso di Storia della Corona d'Aragona (Sassari-Alghero, 1990). Sassari: Carlo Delfino Editore, 1993: II/1, 263-276; Meloni, Giuseppe. "Su alcuni feudatari maggiori e minori in Sardegna all'epoca di Pietro il Cerimonioso". Studi Sardi, 20 (1966): 285-298. Even the process of repopulating Alghero was problematic, partly due to the effects of the Plague, which had invested Iberian territories in that period, but also due to the complex situation in Sardinia and the new scenario of widespread anti-Catalan rebellion which ravaged the kingdom and had grave economic, political and military consequences. See Manca, Ciro. “Notes sobre l'administració de la Sardenya catalana en el segle XIV: 'l'arrendament' de les rendes e drets reyals". Estudis d'Història Medieval, 5 (1973): 73-74.

32. La Sardegna si integra così nell'ingranaggio del potere catalano e persino del 'cursus honorum' degli ufficiali. Molti cavalieri potranno sostenere di aver già compiuto gli obblighi militari dopo aver realizzato $i$ contributi di cavalli armati richiesti per le campagne in Sardegna. La grande maggioranza dei partecipanti alle imprese militari sarde, infatti, invocheranno, al loro ritorno, questi servizi d'armi per essere debitamente ricompensati attraverso l'ottenimento di terre, benefici e incarichi pubblici. In alcuni casi, la compensazione arriva per la scomparsa di familiari che perdono la vita sull'isola per vari motivi (...). In realtà, la Sardegna non godeva di un fascino tale da far abbandonare gli affari e andarvi a combattere come chiedeva il re (...). La guerra e la malattia facevano sì che dalla Catalogna l'isola potesse essere vista come una tenebrosa isola di pena e castigo ("Sardinia is thus part of the mechanism of Catalan power and even of the 'cursus honorum', the sequential order of public offices. Most knights could consider their military obligations fulfilled after having provided the requested number of armed horses for campaigns in Sardinia. On their return from Sardinia, most of those who took part in these military campaigns expected their services to be duly rewarded through concessions of land, benefits and appointments to public offices. In certain cases, compensation arrived through the disappearance of family members who die on the island for various reasons (...). In actual fact, Sardinia was not such an attraction as to abandon businesses in order to take part in the campaigns, as the king requested (...). War and illness were such that the Catalonians saw [Sardinia] as a bleak island of pain 
Subsequently, and especially after the war, the presence of these centres of Iberian origin in the island's most important cities was a key factor in maintaining and consolidating the Catalan occupation of Sardinia, as well as in integrating the Kingdom of Sardinia and Sardinians in the territory of the Crown of Aragon.

It is more difficult to quantify and define Catalan-Aragonese migration within the island; however, the fact that some royal functionaries and feudal administrators in branches of the Sardinian Parliaments came from Barbagia, the most impervious and remote area of the island said to have a strong spirit of resistance, testify to its having taken place. $^{33}$

\section{The diffusion of migrations from the $15^{\text {th }}$ century onward}

Starting in the $15^{\text {th }}$ century, migratory movements between the Iberian peninsula and Sardinia aimed to solve the centuries-old Sardinian-Catalan conflict. This gradually led to the integration of the island in the Hispanic world, despite the Kingdom of Sardinia's obvious position of disadvantage with respect to other kingdoms under the Crown of Aragon. ${ }^{34}$

As a result, even Sardinian society began, or continued with renewed vigour, the process of creating a local Iberian culture; political-economic links, as well as social

and punishment"). Sabaté Curull, Flocel. "Prefazione", Cioppi, Alessandra. Le strategie dell'invincibilità. Corona d'Aragona e 'Regnum Sardiniae' nella seconda metà del Trecento. Cagliari: AM\&D Edizioni-CNR-Isem, 2012: 11-22.

33. In this context, viceroy de Solís Valderrábano's $17^{\text {th }}$ century celebration of the parliament in Sardinia (1698-1699) is worthy of note. Fra' Salvatore Cuy, a provincial vicar and general mayor representing the encontrada real of Barbagia di Belvì - one of the most rebellious and resistant areas of the island according to Giovanni Lilliu, who declared that dicha encontrada no fue conquistada ni fue del marqués de Oristan ni de ningun baron sino voluntariamente presentada a los serenissimos rey(es) de Aragon ("this district was not conquered, nor did it belong to the Marquis de Oristan or any other baron until it willingly submitted to the kings of Aragon"), thereby attesting to the strong early integration of Iberians in the Sardinian population. See Il Parlamento del viceré Giuseppe de Solís Valderrábano, conte di Montellano. Acta Curiarum Regni Sardiniae, eds. Giuseppina Catani, Carla Ferrante. Cagliari: Consiglio Regionale della Sardegna, 2004: II, 984.

34. Manconi, Francesco. “'De no poderse desmembrar de la Corona de Aragón': Sardegna e Paesi catalani, un vincolo lungo quattro secoli". Archivio Sardo. Rivista di Studi storici e sociali, 1 (1999): 43-65; Anatra, Bruno; Manconi, Francesco, eds. Come governare un regno: centro madrilegno e periferia sarda nell'età di Filippo II, Cagliari: AM\&D Edizioni, 1999: 283-302; Belenguer Cebrià, Ernest. “El reino de Cerdeña de Fernando II a Carlos V: el largo camino hacia la modernidad", De la unión de coronas al Imperio de Carlos V, Ernest Belenguer Cebrià, ed. Madrid: Sociedad Estatal para la Conmemoración de los Centenarios de Felipe II y Carlos V, 2001: II, 15-53; Manconi, Francesco. Una piccola provincia di un grande impero. La Sardegna nella monarchia composita degli Asburgo (secolo XV-XVIII). Cagliari: Cuec Editrice, 2012. See also Anatra, Bruno. "Sardegna e Corona d'Aragona nell'età moderna", I Catalani in Sardegna, Jordi Carbonell, Francesco Manconi, eds. Cinisello Balsamo: Silvana Editoriale, 1984: 59-65; Anatra, Bruno. Istituzioni e società in Sardegna e nella Corona d'Aragona (secc. XIV-XVII). El arbitrio de su livertad. Cagliari: AMED Edizioni, 1997 and Cioppi, Alessandra. "Cerdeña, entre Europa y el Mediterráneo. Continuidad y memoria a través de cuatrocientos años de historia ibérica", 'El que del amistad mostró el camino'. Omaggio a Giuseppe Bellini, Patrizia Spinato Bruschi, ed. Cagliari: Isem-CNR, 2013: 41-64. 
and cultural relations, between the states of the Iberian Confederation increased in frequency and importance. ${ }^{35}$

Staring in the 1990 's many studies were undertaken on aspects of $14^{\text {th }}$ to $17^{\text {th }}$ century Sardinian-Iberian social history. These studies shed light on this great demographic movement: the origin of families and their family ties; their relationship with the Iberian regions not only from an administrative and institutional standpoint but also from a cultural and personal one; ${ }^{36}$ the mechanisms regulating the transfer of power and the role of certain clans, representing the situation at the time in its complexity and different forms, as well as the framework of productive systems and of social organization. ${ }^{37}$

35. Manconi, Francesco. “L'eredità culturale”, I Catalani in Sardegna, Jordi Carbonell, Francesco Manconi, eds. Cinisello Balsamo: Silvana Editoriale, 1984: 217-237; Manconi, Francesco. “Traffici commerciali e integrazione culturale nel Mediterraneo occidentale fra Quattrocento e Cinquecento". Studi Storici, 4 (1995): 1051-1073; Manconi, Francesco. "Catalogna e Sardegna: relazioni economiche e influssi culturali fra Quattro e Cinquecento", La Sardegna e la presenza catalana nel Mediterraneo. VI Congresso (III Internazionale) dell'Associazione Italiana di Studi Catalani (Cagliari, 1995), Paolo Maninchedda, ed. Cagliari: Cooperativa Universitaria Editrice Cagliaritana, 1998: I, 35-54; Violant Simorra, Ramon. “Paral-lelism culturals entre Sardenya, Catalunya i Balears". Studi Sardi, 9 (1950): 277-298; Anatra, Bruno. "Economia sarda e commercio mediterraneo nel basso medio e nell'età moderna", Dagli Aragonesi alla fine del dominio spagnolo. III Storia dei Sardi e della Sardegna, Massimo Guidetti, ed. Milan: Jaca Book, 1989: 109216; Salvador Esteban, Emilia. La economía valenciana en el siglo XVI (comercio de importación). Valencia: Universidad de Valencia, 1972 and Esteban, Emilia. “Aproximación al tráfico marítimo entre la isla de Cerdeña y la ciudad de Valencia en el siglo XVI", XIV Congresso di Storia della Corona d'Aragona (SassariAlghero, 1990). Sassari: Carlo Delfino Editore, 1993: II/2, 769-787; Igual Luis, David. Valencia e Italia en el siglo XV: rutas, mercato y ombres de negocios en el espacio economico del Mediterraneo occidental. Valencia: Bancaixa, 1998.

36. Some noble families of Catalan and Valencian origin were viceroys or royal functionaries. This is the case of the Centelles, Cardona, Erill and Crespí de Valldaura families. See Mateu Ibars, Josefina. Los virreyes de Cerdeña. Fuentes para su estudio. I (1410-1623), II (1624-1720). Padua: Cedam, 1964; Floris, Francesco. Feudi e Feudatari in Sardegna. Cagliari: Edizioni della Torre, 1996; Pons Alós, Vicente. “La documentación real del fondo Cerdeña en el Archivo Condal de Orgaz. La formación de un patrimonio: de los Aragall y Bellit a los Gualbes y Brondo", XIV Congresso di Storia della Corona d'Aragona (SassariAlghero, 1990). Sassari: Carlo Delfino Editore, 1993: II/2, 715-745; Chiner Gimeno, Jaime José. “Los 'estados' en Cerdeña de la casa de Oliva durante el siglo XVI. Documentos en el Archivio del reino de Valencia", XIV Congresso di Storia della Corona d'Aragona (Sassari-Alghero, 1990). Sassari: Carlo Delfino Editore, 1993: II/ 1, 291-304.

37. Olla Repetto, Gabriella. "La società cagliaritana nel '400", Cultura quattro-cinquecentesca in Sardegna. Retabli restaurati e documenti. Cagliari: Soprintendenza ai Beni Ambientali Architettonici, Artistici e Storici, 1985: 19-24 and by the same author Olla Repetto, Gabriella. "L'organizzazione del lavoro a Cagliari tra ‘400 e '500: la confraternita dei falegnami", Sardegna, Mediterraneo e Atlantico tra Medioevo ed Età Moderna: Studi storici in memoria di Alberto Boscolo. I. La Sardegna, Luisa D'Arienzo, ed. Rome: Bulzoni Editore, 1993: 429449; Tore, Gianfranco. "Ceti sociali, finanze e 'buon governo' nella Sardegna spagnola (1620-1642)", XIV Congresso di Storia della Corona d'Aragona (Sassari-Alghero, 1990). Sassari: Carlo Delfino Editore, 1993: IV, 477496; Mattone, Antonello, ed. Corporazioni, gremi e artigianato tra Sardegna, Spagna e Italia nel Medioevo e nell'età moderna (XIV-XIX secolo), Cagliari: AM\&D Edizioni, 2000; Oliva Anna Maria; Schena Olivetta. "Il Regno di Sardegna tra Spagna e Italia nel Quattrocento. Cultura e società: alcune riflessioni", Descubrir el Levante por el Poniente, Luciano Gallinari, ed. Cagliari: Istituto sui rapporti italo-iberici-Consiglio Nazionale delle Ricerche, 2002: 101-134; Manconi, Francesco. “Un letrado sassarese al servizio della monarchia ispanica. Appunti per una biografia di Francisco Ángel Vico y Artea", Sardegna, Spagna, Mediterraneo dai Re Cattolici al Secolo d'Oro, Bruno Anatra, Giovanni Murgia, eds. Rome: Carocci, 2004: 291-333. 
Although with some difficulty due to the scarcity of notary acts, family records, chronicles and literary works, in recent years the Italian National Research Council's Institute for the History of Mediterranean Europe has undertaken a series of studies on the city of Cagliari and its late medieval society; these comprise prosopographies and studies on individual families that provide an accurate reconstruction of relationships and dynamics among the different family groups, unveiling the complexity of Cagliari's social fabric from the $14^{\text {th }}$ to the $16^{\text {th }}$ century. ${ }^{38}$

\section{Conclusions}

The situation becomes increasingly complex and interesting, and because there are numerous aspects that would merit further analysis but cannot be correctly addressed herein, it is best to conclude with two considerations, bearing in mind the complexity of migrations in Sardinia.

First, having mentioned prosopography, one must stress how this methodological approach can yield excellent results in reconstructing social ties between Sardinia and the Mediterranean, thereby providing insight into the types and causes of migrations in Sardinia. Second, by constructing prosopographies of individual categories and classes — nobles, feudal lords, officials, merchants - it is possible to analyse the processes of discrimination and consequently of society's integration and naturalization of immigrants.

In our specific case, therefore, it goes without say that it is possible to assess how Catalans, Aragonese, Valencians and other migrants of varied Iberian provenance became rooted on the island, becoming territorially and politically "Sardinians" and thereby contributing to the transformation of the very concept of "Sardinian" discussed earlier. ${ }^{39}$ Furthermore, it is possible to assess both the level of integration

38. Meloni, Maria Giuseppina, ed. Élites urbane e organizzazione sociale in area mediterranea fra tardo medioevo e prima età moderna. Seminario di studi (Cagliari, 2011), Cagliari: Isem-Centre Nazionale delle Ricerche, 2013; Oliva, Anna Maria; Schena, Olivetta. "I Torrella, una famiglia di medici tra Valenza, Sardegna e Roma", Alessandro VI. Dal Mediterraneo all'Atlantico, Miriam Chiabò, ed. Rome: Roma nel Rinascimento, 2004: 115-146; Oliva, Anna Maria. “Bartolomeo Gerp giurista e bibliofilo a Cagliari alla fine del Quattrocento". Acta Mediaevalia, 26 (2005): 1073-1094 and Oliva, Anna Maria. “Andrea Sunyer cittadino di Cagliari e corsaro nella guerra luso-castigliana (1475-1476)", Estudos em homenagem ao professor Doutor José Marques. Porto: Flup, 2006: I, 245-257; Cioppi, Alessandra. "La cavalleria a Castell de Càller nella seconda metà del Trecento. Costruzione di un'élite urbana attraverso un'indagine microstorica", Élites urbane e organizzazione sociale in area mediterranea fra tardo medioevo e prima età moderna. Seminario di studi (Cagliari, 2011), Meloni, Maria Giuseppina, ed. Cagliari: Isem-Centre Nazionale delle Ricerche, 2013 : 135173. To collect and divulge the immense quantity of information derived from these studies, the Institute for the History of Mediterranean Europe has compiled a database that can be accessed from the Institute's webpage Sini, Giovanni, La società cagliaritana tra Medioevo ed Età Moderna, Istituto di Storia dell'Europa Mediterranea, Consiglio Nazionale delle Riceche, 20 June 2016 <http://www.isem.cnr.it/Cagliari/>.

39. Narbona Vizcaíno, Rafael. “Las ciudades de los reinos insulares de la Corona de Aragón. Historia municipalista e historia de la sociedad urbana", Chiesa, potere politico e cultura in Sardegna dall'età giudicale al Settecento. II Convegno Internazionale di Studi (Oristano, 2000), Giampaolo Mele, ed. Oristano: ISTAR, 2005: 627-641. 
of Iberian and second generation Sardinian-Iberian families and, vice versa, the level of integration of those who left the island to settle in the various states under the Crown of Aragon, attempting to trace their history and migrations in a Mediterranean without frontiers. 